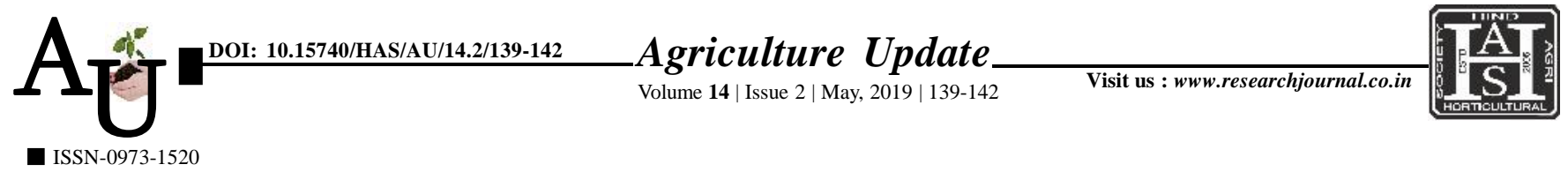

\title{
Research Article: Adoption of technologies in non-wood forest products (NWFPs) among tribal women in Coimbatore district
}

\author{
Article Chronicle: \\ Received : \\ 13.02.2019; \\ Revised : \\ 11.04.2019; \\ Accepted : \\ 13.05.2019
}

KEY WORDS:

Tribal, Forest, Non-wood forest products

\section{P. Balasubramaniam, Ramanuj Banerjee and N. Suganthi}

SUMMARY : Non-wood forest products (NWFPs) play a key role in the life and economy of communities living in and around forests. NWFPs have a tremendous potential to create large scale employment opportunity thereby helping in reducing poverty and increasing empowerment of particularly tribal. Tribes depend upon forests for their existence in several ways. Their degree of dependence varies with several factors including socio-economic conditions, distribution, cultural and religious norms, literacy etc., The people, mainly tribals living within or in the margin of forest areas collect non-timber forest products in their daily life. The primitive tribes, who are living inside dense forests are very poor and depend entirely on forests for meeting most of their needs. The present study tries to explore the importance of NWFPs on livelihood of the tribal people. Continuous field survey and interview were done with a structured questionnaire for data collection. In this paper involvement of tribal people in non-wood forest product (NWFPs) activities in Coimbatore district is presented. A sample size of 150 respondents was selected for the study.

How to cite this article : Balasubramaniam, P., Banerjee, Ramanuj and Suganthi, N. (2019). Adoption of technologies in non-wood forest products (NWFPs) among tribal women in Coimbatore district. Agric. Update, 14(2): 139-142; DOI : 10.15740/HAS/AU/14.2/139-142. Copyright@ 2019: Hind Agri-Horticultural Society.
Author for correspondence :

\section{N. Suganthi}

Department of Agricultural Extension and Rural Sociology, Tamil Nadu Agricultural University, Coimbatore (T.N.) India

Email: suganthiextn@ gmail.com

See end of the article for authors' affiliations 